\title{
A questão racial na ordem do dia: retomando debates
}

\author{
Comissão Editorial
}

Em 2011 foi declarado o Ano Internacional dos Povos Afro-descendentes pela Organização das Nações Unidas ${ }^{1}$, ano no qual ainda se comemora o $10^{\circ}$ aniversário da III Conferência Mundial de Combate ao Racismo, Discriminação Racial, Xenofobia e Intolerância Correlata de Durban, que aprovou, em 2001, medidas de cooperação internacional e regional para o fomento a políticas públicas em benefício dos afro-descendentes. Instigada por essa proposta de pensar o combate ao racismo, à discriminação e a promoção do respeito à diversidade cultural, a Cadernos de Campo, nesta seção Especial, apresenta um conjunto de artigos que abrange, sob variados temas, questôes relacionadas aos estudos das populaçóes afro-descendentes. Para isso, convidamos autores que tem expressivas pesquisas sobre essas populaçóes, e que resultaram em reflexóes inéditas, atualizando os debates e lançando um novo olhar sobre as problemáticas existentes.

A questão étnico-racial está colocada na ordem do dia! Raças, racismos, identidades nacionais e novos nacionalismos, diáspora africana, intolerância religiosa, processos migratórios, memórias, conflitos territoriais, ações afirmativas, entre outros, são assuntos debatidos no momento, tendo em vista as pesquisas acadêmicas, propostas políticas, noticiário da imprensa e os discursos dos movimentos sociais. Assuntos estes aqui contemplados, em artigos escritos por pesquisadores de diferentes tradiçôes teóricas sobre o negro brasileiro, colombiano e haitiano.
Antonio Sérgio Guimarães inicia nossa coletânea destacando a importância do conceito de raça na construção do Brasil como nação. Em Raça, Cor, Cor da Pele e Etnia, traça a trajetória do termo raça, desde seu uso para fomentar a política racial no país - a mestiçagem e o embranquecimento -, seu banimento do nosso vocabulário pelas tragédias mundiais causadas pelo racismo, até sua retomada na linguagem atual. Hoje, raça, enquanto classificador social, é utilizado com sinal invertido, "como estratégia política para incluir, não para excluir, de reivindicar e não de sujeitar”. Ao assinalar suas vantagens estratégicas, o autor reconstitui a recuperação do termo na luta política e sua incorporação na sociologia contemporânea como conceito nominalista. Guimarães, levando em consideração estes desdobramentos recentes do termo raça, nos apresenta outra mudança importante: o sistema de classificação racial por cor vem sendo modificado no Brasil, à medida que o ideal de embranquecimento perde força, e a cor vem sendo substituída pela cor da pele como critério de classificação.

$\mathrm{Da}$ noção de raça ao racismo, Omar $\mathrm{Ri}$ beiro Thomaz, em "Eles são assim": racismo e o terremoto de 12 de janeiro de 2010 no Haiti, tem como ponto de partida uma etnografia dos dias que sucederam aos terremotos no país, e coloca o racismo manifestado quando se trata de enfrentar a situação contemporânea do Haiti a partir de uma análise dos motivos pelos quais a cooperação internacional fracassara. Com riqueza de dados etnográficos, o texto de Thomaz é um convite a repensar o racismo em 
262 Comissão Editorial

relação ao Haiti e as causas do ostracismo ao qual foi relegado, quando aponta a negação, por parte da comunidade internacional, da possibilidade de haver uma civilização haitiana e a incapacidade de seus habitantes para a reconstrução. A história ignorada de um país de maioria negra tem aí o seu porquê: "Por conta dos que continuam acreditando no sentido da raça”. Ao refletir sobre racismo, o autor vai problematizar o modo pelo qual os haitianos são tomados em discursos e políticas empenhadas após os terremotos; são objetos, nunca considerados sujeitos, apesar dos eventos revelarem o fracasso do mundo ali construído pelos brancos: o mundo da ajuda internacional.

Em seguida, no âmbito de pesquisas realizadas em contextos reivindicatórios de direitos e políticas diferenciadas, José Maurício Arruti, no artigo Diferenciar, Redistribuir, Reconhecer: Ensaio de atualização dos debates sobre terras e educação para quilombos, aponta um novo momento histórico para o debate sobre a questão racial no Brasil, no qual a população negra rural ganha grande visibilidade. Ao considerar as diversas respostas do Estado brasileiro a essa nova realidade, o autor refaz o caminho das diferentes portarias, normativas, projetos de lei e decretos, os quais regeram o cenário do reconhecimento de direitos de comunidades remanescentes de quilombos a partir da década de 1990, sobretudo atualizando os debates ocorridos na última década, que incorporam a questão quilombola na variedade de políticas de responsabilidade pública. $\mathrm{O}$ autor conclui que tal reconhecimento implica em um reforço e uma correção das políticas de redistribuição, as quais decorrem reflexões sobre política diferenciada, por um lado, e um tratamento diferenciado no acesso a políticas indiferenciadas, por outro. Arruti aborda o contexto atual em duas destas políticas, tomando os embates em torno da política de terras e os debates em torno da política de educação, convidando a pensar "em que medida e que termos situar a diferença quilombola".

Em Religião e Identidade Cultural Negra: Católicos, Afro-Brasileiros e Neopentecostais, Vagner Gonçalves da Silva analisa os papéis das religiōes afro-brasileira, católica e neopentecostal no processo de disputa dos símbolos da herança negra no Brasil. Segundo o autor, a construção das identidades culturais de origem negra esteve durante muito tempo vinculada às religiōes afro-brasileiras, no entanto isto tem mudado nas últimas décadas. As pastorais católicas afro e os movimentos negros evangélicos estão buscando também, a seu modo, afirmar uma identidade negra. Nesse sentido, o Brasil de hoje vive sob um dilema entre convicçóes religiosas e políticas de apelo étnico, uma "encruzilhada de valores religiosos e açóes políticas”. Católicos, neopentecostais e os adeptos das religióes afro estão reivindicando para si um campo legítimo de aplicação de políticas públicas voltadas a populaçôes afro-brasileiras. Ao pensar as formas pelas quais essas religióes se relacionam com os agentes sociais e políticos, Silva nos traz posicionamentos inusitados sobre sincretismo, mestiçagem, herança africana, cultura brasileira e participação política.

Ressaltando também a interface com ações do Estado e contextos reivindicatórios, no artigo Músicas afro-colombianas: entre la espiritualidad y la critica social, Lina del Mar Moreno Tovar examina a relação histórica entre espiritualidade, crítica social e música, tomando criaçóes musicais enquanto centrais para a reprodução cultural dos povos afro-descendentes. Ao considerar a musicalidade como veículo de memórias, o que teria contribuído para a desnaturalização de estereótipos com relação às populaçóes afro-descendentes, a autora pensa o papel da música na construção das representaçóes do negro e no devir histórico dos povos afro-americanos. A análise volta-se para os modos pelos quais a música permanece como veí- 
culo privilegiado para povos afro-descendentes rememorarem sua história como também para expressarem as situações de violência que vivenciam. A reflexão proposta pela autora toma a musicalidade como estratégia de visibilidade social dos afro-descendentes na América, que reivindicam direitos por meio de sua criação musical, considerada patrimônio cultural, buscando uma melhor compreensão da diversidade, assim como propostas de políticas direcionadas que possam ir além de estereótipos e expectativas raciais.

Esperamos que as contribuições aqui reunidas possam proporcionar material para reflexão sobre tantos dilemas e impasses que permanecem presentes no campo de estudo das relaçóes raciais e de pesquisas com as populaçóes afrodescendentes. Em um contexto mundial no qual as categorias raça, etnia e cultura oscilam entre usos analíticos, políticos e nativos, servindo ainda de fontes irradiadoras de direitos ou de barreiras ao reconhecimento dos mesmos, ampliar a compreensão sobre os diversos contextos sociais, políticos e históricos em que se encontram os povos e comunidades afro a partir de diferentes experiências de pesquisa é o objetivo para o qual este Especial visa colaborar.

\section{Notas}

1. A Assembleia Geral das Naçóes Unidas (ONU), por meio da Resolução A/RES/64/169, e pela Organização dos Estados Americanos (OEA), Resolução AG/ RES. 2550, declarou 2011 o Ano Internacional dos Povos Afrodescendentes, com objetivo de fortalecer medidas e cooperação em benefício dos afrodescendentes, com viés voltado aos direitos econômicos, culturais, sociais, civis e políticos, incluindo a participação e inclusão e a promoção de maior respeito e conhecimento da diversidade, sua herança e sua cultura. 